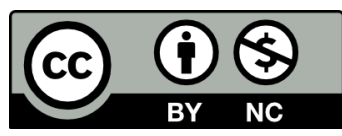

\section{Leading Reflective Practices in Montessori Schools}

Sharon Damore and Barbara Rieckhoff, DePaul University

Keywords: instructional supervision, Montessori leadership, educational leadership, school administration

\begin{abstract}
In this paper, we report the results of a qualitative study examining the development of leadership competencies as Montessori school leaders gain experience using a coaching protocol with their teachers. Extending previous work, the emphasis is on the school leaders' specific roles as instructional supervisors leading reflective practices. National standards, both traditional and Montessori, are a foundation to investigate a group of Montessori school leaders' development in reference to articulated competencies, specifically for the school leader to tend to their own learning and effectiveness through reflection, study, and improvement, and to empower teachers to the highest levels of professional practice and to continuous learning and improvement. After the use of a prescribed coaching protocol, 12 Montessori school leaders from 6 schools across the United States were interviewed using a set of semistructured questions. The study results support that reflective practices lead to both improvement of practice with this group of Montessori school leaders and their respective teachers. We conclude that self-reflection is critical to a Montessori leader's success, empowering them to model and influence reflective practices, with direct impacts on teacher reflection and school improvement. This conclusion becomes relevant as we observe our Montessori school leaders assuming numerous and complicated administrative roles, from management and teacher evaluation to instructional supervision, mentoring, and coaching teachers.
\end{abstract}

The role of the school leader is complex, with multiple duties and assignments (Bouchamma \& Basque, 2012; Hallinger \& Heck, 2011), as outlined in the national professional standards for educational leaders (National Policy Board for Educational Administration [NPBEA], 2015). Comprehensive and covering critical learning and applications for principals and other school leaders, the professional standards for educational leaders (PSEL; NPBEA, 2015) emphasize the delivery of a school vision, the role of instructional leadership, and the relationship between educational leadership and student learning. These national standards are a foundation for investigating a group of Montessori school leaders' development in relation to the standards' articulated competencies, more specifically for school leaders (a) to tend to their own learning and effectiveness through reflection, study, and improvement and (b) to empower and motivate teachers and staff to the highest levels of professional practice and to continuous learning and improvement (NPBEA, 2015, p. 20). A qualitative inquiry process examined the development of these competencies in Montessori school leaders using a coaching protocol with their teachers. This study extends previous work (Damore \& Rieckhoff, 2019; 
Rieckhoff \& Damore, 2017) by continuing to study school leaders in their roles as instructional supervisors. We conclude that self-reflection is critical to a Montessori school leader's success, a process that empowers them to model and influence reflective practices, with direct effects on teacher reflection and school improvement. This conclusion becomes relevant as we observe our Montessori school leaders assuming numerous and complicated administrative roles from management, and teacher evaluation to instructional supervision and guiding teachers. As our previous work used the term "coaching," we have aligned coaching to "guiding," which is more recognizable in Montessori teacher education.

\section{Research Questions and Terminology}

Two research questions guided this study: How can a Montessori school leader's self-reflection be facilitated through the use of a prescribed coaching protocol? How does the use of a prescribed coaching protocol impact the Montessori school leader's ability to lead teachers in reflective practices?

Numerous authors distinguished between roles of coaching, mentoring, and supervision (Brockbank \& McGill, 2012; Nolan \& Hoover, 2008), but Brockbank and McGill (2012) described processes of reflective practice across all three roles. Nolan and Hoover (2008) differentiated between teacher evaluation and supervision, emphasizing the latter as the setting in which leaders support growth in their teachers. Depending on the Montessori school, coaching responsibilities were assigned to all school leaders: administrators; program directors; and instructional supervisors, mentors, or coaches. For the purpose of this study, these terms were used interchangeably because, regardless of title, all of these school leaders were delegated the task of instructional supervision of teachers. Within many of our Montessori schools, we found these roles ambiguous and intertwined, which may result in challenges in teacher improvement. Our intention was not to include the coaching protocol within the context of a teacher-performance evaluation system, but to examine improvement of reflective practices with the participants and their teachers. In the context of this discussion, "student" and "child" are used interchangeably.

\section{Literature Review}

Our questions focused on Montessori school leaders' reflective practice, individually and with teachers, and how these school leaders might acquire these competencies and incorporate them into their roles as instructional coaches. Much of the contemporary, mainstream educational coaching and mentoring literature examines teachers' engagement in reflective practices, how those phenomena are structured and delivered, and the effects on teaching and learning. National and state professional standards articulate the inclusion of this skill set and expertise in school-leader preparation (NPBEA, 2015). National Montessori accreditation standards (American Montessori Society [AMS], 2018) include expectations of similar competencies of the school leader through the delivery of a shared philosophy that guides the school's culture, including instructional decisions, and the development of the teacher (AMS, 2018, Standard 1, Standard 5, pp. 2-10).

Reflective practice, which can be traced to Maria Montessori's work in 1907 (Saylor et al., 2018), represents a cyclical process of deep reflection describing one's professional thinking as a pathway to improved teaching practices (Saylor et al., 2018). Dewey (1933) espoused its importance and posited reflective thinking as distinct from other forms of thought. A connection exists between experiential learning and reflection: the process of "reflective action" (Bouchamma \& Basque, 2012, p. 627), which builds new knowledge and decision-making for the school leader. Dr. Montessori's view of leadership emanates from a nontraditional lens, with leadership development embedded in practice and in children as an "investment in human capital" (Bagby \& Sulak, 2013, p. 6). She described leadership development through self-awareness, self-regulation, and self-motivation. As students develop leadership skills through orienting and valuing themselves, they are in turn able to explore their place in a larger society. Dr. Montessori's view of leadership was authentic, with transferable skills applied to the student, teacher, and school leader: "Anyone who wants to follow my method must understand that he should not honor me, but follow the child as his leader" (Montessori, 1970, para. 33). Dr. Montessori's writings include leadership concepts of transformation, 
adaptation, service, humility, contextual elements, and spirituality. While these ideas align with elements of transformational, moral, and servant leadership theories and models, Dr. Montessori's leadership framework was distinct. Her view of leadership was a bottom-up approach, in contrast to many top-down approaches; the actions of the leader are similarly situated from the ground up, from student to teacher to leader.

\section{Leader Self-Reflection}

Dr. Montessori suggested that a vital component of the leadership role is self-reflection: "Those who direct others must themselves be transformed. No one can ever be a leader or a guide who has not prepared for that work" (Montessori, 1949/1984 as cited in Bennetts \& Bone, 2020, p. 5). A leader's self-reflection signals a readiness to guide the work and to change, and a willingness to challenge current practices and beliefs (Senge et al., 2012). Professional reflective practice, described by Meier and Henderson (2007), can be viewed as educators' exhaustive study of themselves (Saylor et al., 2018). Reflective leaders can improve their own effectiveness and influence the reflective practices of other adults in their school communities (York-Barr et al., 2016, p. 152). Argyris and Schön (1974) differentiated single- and double-loop learning in relation to reflective practice. Single-loop learning involves observing previous action, reflecting on what has been done in order to change the next action (Senge et al., 2012, p. 151). Senge et al. (2012) described double-loop learning, which occurs during reflection and forces leaders to think outside of their usual sources of information. Applying double-loop learning to a school setting, the principal amplifies the reflection to include analysis of choices and decisions regarding classroom improvement. Houchens and Keedy (2009) further espoused the framework of theories of practice, a process emphasizing the need for self-reflection in order to consider other perspectives as principals lead communities of reflective practice in their schools. Houchens et al. (2017) further extended the research, suggesting school leaders'

effectiveness requires subsequent willingness to alter their assumptions, values, and beliefs as they address complex problems and issues. Within the context of theories of practice, the individual contemplates alternative perspectives, which results in new action or direction. If the leader can practice and model this double-looping with teachers, then the process can be expanded to the school-improvement process, thus creating a reflective professional learning community that begins with the leader.

\section{Leading Reflective Practice}

Dr. Montessori described leading others in reflective practice in much the same way that the teacher leads the child, acknowledging the importance of charisma, enticing others into the activity: "Leadership ... is enacted through the goal of supporting the free, independent development of the human personality" (Bennetts \& Bone, 2020, p. 5). The leader guides others, who are in turn responsible for their own skills. Professional reflection is a starting point for teachers to take charge of their own learning (Saylor et al., 2018). The impact of school leaders on their school communities cannot be underestimated. Reflective learning is a frequent component of professional development (Saylor et al., 2018). The instructional leader must embrace, practice, and refine reflection skills to guide the reflective practices of teachers: "Awareness of one's own intuitive thinking usually grows out of practice in articulating it to others" (Schön, 1983, p. 243). Feelings of isolation can be minimized, relationships can be strengthened, and these thinking partnerships can "increase a sense of belonging and connectedness in our work" (York-Barr et al., 2016). Coaching and its role in a school leader's work is particularly germane in the Montessori context (Saylor et al., 2018). The success of coaching depends upon recognizing and honoring a teacher's autonomy (Knight, 2019). As with their students, teachers have little motivation to learn, change, and grow if they do not have autonomy or choices. Montessori practices support autonomy for students, teachers, and leaders. Aguilar (2013) suggested coaching as an essential component of professional development by "creating a relationship in which a client feels cared for ... and able to access new knowledge" (p. 8), which is central to a Montessori classroom.

\section{Adult Learning Principles for Leading Reflective Practice}

Dr. Montessori viewed training as "a natural process which spontaneously develops in the human being" (Montessori, as cited in Bennetts \& Bone, 2020, p. 5). The teacher is not an imitator, but rather a thinking teacher, 
one on a moral quest. Montessori training becomes more than the knowledge of curriculum; it is participation in a way of life, where the soul of learning is rooted in the development of the child. More importantly, the teacher's preparation must be a self-transformation, so that the teacher is not the obstacle to the process (Bennetts \& Bone, 2020, p. 6). As these Montessori principles are modeled from teacher to child to school leader to teacher, they align with adult learning principles and are a critical subset of leading reflective practice. Steiner (2016) suggested the importance of giving teachers the time and space to reflect upon their practice, affording them "the freedom to learn" (p. 422). Caffarella and Daffron (2013) connected adult learning and reflective practices, concluding that recognition and respect for adults is essential in planning professional development. In this study, we label the coaching protocol as a form of professional development, with deep consideration of adult learning principles that parallel Montessori principles of auto-education, spiritual freedom, and respect for the individual's autonomy.

Dialogue and trust are important cornerstones for lasting adult learning (Drago-Severson et al., 2013; Tschannen-Moran \& Gaereis, 2015). Defined by DragoSeverson et al. (2013), dialogue is creating a mutual feeling of shared purpose and direction, acknowledging and appreciating feedback, rather than viewing it as a threat to participants. Thinking together means moving forward beyond an initial position of resistance or lack of objectivity, encouraging openness to possibilities (York-Barr et al., 2016). It is essential to provide teachers coaching environments and conversations deemed safe. Trust is described as an indispensable condition needed to foster reflective practice. Tschannen-Moran and Gaereis (2015) believed trust requires constant attention; learning increases when trust is present. Reflective leadership is modeled and practiced, and it invites teachers to join the process. Dr. Montessori's views, which underscore the teacher's role in preparing future leaders, are echoed in Montessori schools' standards (AMS, 2019). Teachers serve as guides and mentors rather than dispensers of knowledge. Dr. Montessori's writings underscore the trust the teacher must have in children to reveal themselves in their work (Montessori, 1984). The school leader needs to apply that level of trust to the teacher. Leaders provide a trusting collegial relationship that honors adult learning and corresponding teacher needs and interests. These processes, when embedded in a school's culture, allow openness to school improvement, individual responsibility, and accountability, with the potential for real and lasting change in schools.

\section{Reflective Practice for School Improvement}

Moving school leaders and teachers through selfreflection, as partners, is a first step in using the power of reflective practice to improve schools. As a culture of trust and openness emerges for all stakeholders, the possibilities of school change are available to all. According to Senge et al. (2012), communities of reflective practice are a powerful model for schools to achieve high levels of student learning: "School quality manifests itself in the quality of conversations in the school" (York-Barr et al., 2016, p. 33). With schoolimprovement efforts, reflective practices emerge as critical behaviors as defined by educational preparation standards, such as the National Board Teaching Standards, National Leadership Standards (NPBEA, 2015), and in Danielson's teaching rubric (Saylor et al., p. 13). The AMS standards require the school to document and use results for learner outcomes: "The quality Montessori school enacts an ongoing assessment system that monitors and documents learner outcomes, and uses these results to improve educational effectiveness" (AMS, 2018, p. 9). However, Dr. Montessori suggested that improving schools is not a top-down, hierarchical process but rather a bottom-up process starting with the child. Instead of focusing on improving test scores or other external measures of the school's success, the Montessori view focuses on each human being, with the leader's role one of responsibility and not authority (Bennetts \& Bone, 2020, p. 9). Dr. Montessori visualized a bigger, global perspective to improve the social order, taking care of our civilization and our world (Montessori, 1984). Challenges facing school leaders increase and deepen, often mirroring those faced in society. Elliot and Shiff (2001) emphasized the importance of providing educators with opportunities to speak about equity issues, ranging from curricular to organizational concerns. Cultural diversity and equity are primary considerations in school-improvement efforts as leaders are faced with addressing racial disparity and inequities. 


\section{Methods}

The study followed a naturalistic, holistic, multicasestudy research design (Bogdan \& Biklin, 2007; Glesne, 2011; Zainal, 2007). Results were clarified and strengthened through explanatory building, and we determined data appropriateness for the research question and theoretical connections (Zainal, 2007). With this study, we continued the examination of the experiences and perceptions of school leaders who used a coaching protocol (Damore \& Rieckhoff, 2019) but specifically focusing on individual self-reflection and leading reflective practices with this group of Montessori school leaders. The theoretical underpinning for this study is grounded in a phenomenological approach of research (Bogdan \& Biklin, 2007; Glesne, 2011).

This interpretive, ethnographic approach led to explanation of interactions and to learning about a social phenomenon when variables are complex, interwoven, and difficult to measure (Glesne, 2011). As in previous research, our approach brought the perspective of university-based faculty working within school communities founded on principles of critical, collaborative inquiry (Clark, 1999). Contextualized in earlier work (Damore \& Rieckhoff, 2019; Kapustka \& Damore, 2012; Rieckhoff \& Damore, 2017) that originated in the examination of the use of a coaching protocol with student teachers, analysis transitioned to studying the coaching protocol with practicing school leaders, including Montessorians.

We are university-based teacher educators, previous administrators of both public and private schools, who coach principals and instructional leaders locally and nationally. One of us is also a Montessori educator with more than 30 years of experience. The transition to study Montessori school leaders occurred when the researcher was asked to assist in developing systems of teacher supervision and feedback in Montessori schools. Classroom observations had been routine, but the administrators struggled to facilitate constructive feedback with their teachers in a timely, meaningful way. For this study, we did not focus on formal teacher evaluation but on strategies of teacher supervision, including building trust and reflective practices with the teachers.

\section{Selection of Participants}

Convenience sampling was used for participant selection to provide rich cases to study the phenomenon of reflective practice in schools (Glesne, 2011). We presented the research opportunity at several regional and national Montessori conferences in the United States. The school administrators who contacted us were invited to participate after we felt confident that the participant was committed to the project. Referencing Hallinger \& Heck (2011), school leadership commitment and capacity are paramount to improvement of academic achievement. We interviewed 12 Montessori school leaders. The first cohort participated during the 2017-2018 academic year and the second cohort in 2018-2019. Participants were provided informed consent, and written teacher consent was obtained. For data analysis, the two cohorts were combined, using standardized training and data-collection procedures. The demographics of the school leaders and respective schools are reported in Table 1 . The sample was not intended to be representative of the populations of schools in which the research was conducted. All participants, regardless of titles, were responsible for the instructional supervision of teachers. While Montessori fidelity and quality of implementation are not part of this study, their schools' accreditations, or other information about their adherence to Montessori standards, are reported in Table 1.

\section{Coaching Protocol—Design and Development}

The coaching protocol is a semistructured set of eight questions used by an instructional supervisor to facilitate feedback to the teacher after a classroom observation. The questions, which use evidence-based components of good teaching and learning, along with solicitation of critical, inquiry-based teacher responses, are designed to enable the supervisor-coach to guide teachers to self-reflect and improve their classroom practices (Yendol-Hoppey \& Dana, 2007). Originally designed and used (Kapustka \& Damore, 2012) with student teachers at a large, urban university, the protocol was developed in response to our participatory experiences in a university-based professional-development school model (Teitel, 2003), as well as a review of the literature that denounced teacher education programs' ineffectiveness. The protocol was designed with the intention of improving the supervisory relationship and teacher efficacy. As with Nolan and Hoover's (2008) perspective on the need to differentiate 
Table 1

Demographics of School-Leader Participants

\begin{tabular}{|c|c|c|c|c|c|}
\hline Pseudonym & $\begin{array}{l}\text { School leadership } \\
\text { title or role }\end{array}$ & $\begin{array}{l}\text { Experience in } \\
\text { administration or } \\
\text { supervision }\end{array}$ & Credentials & $\begin{array}{l}\text { School } \\
\text { demographics (all } \\
\text { in U.S.) }\end{array}$ & $\begin{array}{c}\text { Fidelity / Montessori } \\
\text { implementation } \\
\text { description }\end{array}$ \\
\hline Diane & $\begin{array}{l}\text { Lower Elemen- } \\
\text { tary program } \\
\text { director (grades } \\
1-3 \text { ) }\end{array}$ & $<3$ years & $\begin{array}{l}\text { State and } \\
\text { Montessori } \\
\text { credentials }\end{array}$ & $\begin{array}{l}\text { Public charter, } 200 \\
\text { students, EC-grade } \\
8 \text {, Western state }\end{array}$ & $\begin{array}{l}\text { Adheres to state require- } \\
\text { ment that all teachers } \\
\text { are credentialed at level } \\
\text { of teaching; professes } \\
\text { to adhere to authentic } \\
\text { Montessori standards }\end{array}$ \\
\hline Georgina & $\begin{array}{l}\text { Upper Elemen- } \\
\text { tary program } \\
\text { director (grades } \\
4-6 \text { ) }\end{array}$ & $>10$ years & $\begin{array}{l}\text { State and } \\
\text { Montessori } \\
\text { credentials }\end{array}$ & $\begin{array}{l}\text { Public charter, } 200 \\
\text { students, EC- grade } \\
8 \text {, Western state }\end{array}$ & Same as above \\
\hline Carol & $\begin{array}{l}\text { Instructional } \\
\text { coach }\end{array}$ & $<2$ years & M.Ed. & $\begin{array}{l}\text { Public charter, } 200 \\
\text { students, EC- grade } \\
8 \text {, Western state }\end{array}$ & Same as above \\
\hline Hillary & $\begin{array}{l}\text { Elementary coor- } \\
\text { dinator }\end{array}$ & $<2$ years & $\begin{array}{l}\text { State and } \\
\text { Montessori } \\
\text { credentials }\end{array}$ & $\begin{array}{l}\text { Public charter, } 200 \\
\text { students, EC- grade } \\
8 \text {, Western state }\end{array}$ & Same as above \\
\hline Jackie & Administrator & $<2$ years & $\begin{array}{l}\text { M.F.A., } \\
\text { Montessori } \\
\text { credential }\end{array}$ & $\begin{array}{l}\text { Public charter, } 200 \\
\text { students, EC- grade } \\
8 \text {, Western state }\end{array}$ & Same as above \\
\hline Louise & Principal & $>5$ years & $\begin{array}{l}\text { State and } \\
\text { Montessori } \\
\text { credentials }\end{array}$ & $\begin{array}{l}\text { Private, Catholic, } \\
150+\text { students, EC- } \\
\text { grade } 3 \text {, Midwest- } \\
\text { ern state }\end{array}$ & $\begin{array}{l}\text { School on Step } 6 \text { of } \\
\text { AMS Pathway Program } \\
(\text { AMS, 2021) }\end{array}$ \\
\hline Wilma & Associate HoS & $<4$ years & $\begin{array}{l}\text { Montessori } \\
\text { credential }\end{array}$ & $\begin{array}{l}\text { Private, } 200+\text { stu- } \\
\text { dents, EC-grade } 8 \text {, } \\
\text { Southern state }\end{array}$ & AMS-accredited school \\
\hline Queenie & Associate HoS & $>3$ years & $\begin{array}{l}\text { Montessori } \\
\text { credential }\end{array}$ & $\begin{array}{l}\text { Private, } 200+\text { stu- } \\
\text { dents, EC-grade } 8 \text {, } \\
\text { Southern state }\end{array}$ & AMS-accredited school \\
\hline Kenneth & $\begin{array}{l}\text { Middle school } \\
\text { coordinator }\end{array}$ & $<8$ years & M.Ed. & $\begin{array}{l}\text { Private, } 250+ \\
\text { students, EC-grade } \\
12 \text {, Western state }\end{array}$ & IMC-accredited school \\
\hline Sam & $\begin{array}{l}\text { Middle school } \\
\text { coordinator }\end{array}$ & $>5$ years & $\begin{array}{l}\text { M.A., liberal } \\
\text { arts, Montes- } \\
\text { sori credential }\end{array}$ & $\begin{array}{l}\text { Private, } 250+\text { stu- } \\
\text { dents, EC-grade } 8 \text {, } \\
\text { Western state }\end{array}$ & AMS-accredited school \\
\hline Denise & EC coordinator & $<3$ years & $\begin{array}{l}\text { B.S., Montes- } \\
\text { sori credential }\end{array}$ & $\begin{array}{l}\text { Private, } 250+\text { stu- } \\
\text { dents, EC-grade } 8 \text {, } \\
\text { Western state }\end{array}$ & AMS-accredited school \\
\hline Kelly & EC coordinator & $<3$ years & $\begin{array}{l}\text { B.S., Liberal } \\
\text { arts }\end{array}$ & $\begin{array}{l}\text { Private, } 250+\text { stu- } \\
\text { dents, EC-grade } 8 \text {, } \\
\text { Eastern state }\end{array}$ & AMS-accredited school \\
\hline
\end{tabular}

Note. EC = Early Childhood; HoS = Head of School; M.Ed. = Master of Education; M.F.A. = Master of Fine Arts; M.A. = Master of Arts; AMS = American Montessori Society; IMC = International Montessori Council. 
between teacher evaluation and supervision, the protocol was designed not for formal teacher evaluation, but to increase reflective practice for the instructional supervisor and the teacher. The original name of the coaching protocol was the Reflective Interview Protocol, but it was retitled the Coaching Protocol as it was used by school administrators.

The questions on the protocol address teaching and learning topics of curriculum planning and delivery of instruction, differentiation of instruction, evidence of student learning, adult communication and collaboration, and professionalism and reflective practices. Because of the essentiality of initially training administrators to use the protocol, we intentionally do not share the protocol questions in their entirety. To illustrate the use of the protocol questions presented by the instructional supervisor to the teacher and to facilitate readers' basic understanding of the design and contents of the questions, we highlight an example for readers' rudimentary understanding. One question on the protocol_- "What did your students learn today, and how do you know?"- was guided by earlier research of how teachers (preservice and in-service) articulated their understanding of student learning and how the protocol facilitated responses about the efficacy of teaching and learning (Damore \& Rieckhoff, 2019; Kapustka \& Damore, 2012).

Among participants, reflection as a practice emerged as an overarching theme. With other questions on the protocol, we experienced similar patterns with teachers thinking about, articulating, and engaging in self-inquiry and reflection on the topics of curriculum delivery, differentiation, communication and collaboration, and professionalism and reflective practice. The protocol questions, although originally designed for traditional teachers, were not altered for this study with the Montessori school leaders. However, during our interviews with the leaders, several of them requested clarification to better translate the protocol questions for Montessori classroom practices. A protocol question that focused on curriculum delivery (i.e., "Tell me what you planned for your classroom today and what actually happened") evolved into a discussion between researcher and school leader about Montessori teachers not always using the term "planning." Montessori training may not use planning per se, but parallels are found with an emphasis on following the child, the prepared adult, and the prepared environment for the child's success
(Bennetts \& Bone, 2020). Rather, Montessori teachers do plan lessons according to their observations of the child's choice, use, and mastery of instructional materials. Therefore, we experienced not an alteration of the protocol questions, but rather discussion and further clarification about alignment to Montessori principles.

\section{Data Collection}

We trained the school leaders to use the coaching protocol, conducting on-site visits at the participants' respective schools. Each researcher and participant jointly observed a classroom, which was followed by a teacher conference during which the researcher asked the teacher the interview questions while the school leader observed. The school leader was asked to repeat the process three more times during the academic year with the same teacher or teachers but without the researcher. During the course of the research study, we interviewed the participants via Zoom at midterm and at the end of the academic year. Using a semistructured interview set of questions (see Appendix A), questions for the school leaders focused on strengths, value, areas for improvement, and ease of use of the coaching protocol and process.

\section{Data Analysis}

Eighteen interviews were recorded and transcribed, representing the 12 participants. Because of scheduling and availability, not all participants were available for both midterm and final interviews, thereby limiting the total number of interviews available for data analysis. Four initial codes-based on the research questions, our previous research on the coaching protocol, and a contemporary literature review on reflective practicewere used to analyze the interview data. The codes included school improvement, adult learning principles, individual self-reflection, and leading reflecting practice, and they aligned with concepts found in mainstream leadership theories.

The transcribed interviews were initially analyzed manually through open coding, where segments of data were assigned initial codes, that is, a word or term that attributes meaning to the data (Creswell, 2013). Coding is defined as a "progressive process of sorting and defining ... scraps of collected data ... that are applicable to your research purpose" (Glesne, 2011, p. 194).

The sequence of analysis continued with our creating more-focused and more-selective coding, which involved 
the condensing of initial codes into categories that were further clustered until patterns suggested emergent themes across the data. This process was ongoing until data saturation was achieved and new themes no longer surfaced. We also determined we were double-coding in several instances, with many of the participants' responses overlapping across the themes. We concluded that the themes were not mutually exclusive. The final debriefing confirmed three major themes: (a) individual reflection by the leader themselves, (b) leading reflective practice with an application of the principles of adult learning, and (c) reflection for school improvement. These themes are grounded in the literature and the ongoing, collaborative debriefing between the two researchers that provided an organizational road map for the Findings and Discussion section.

\section{Trustworthiness and Limitations}

Glesne (2011) presented trustworthiness as a means to increase the credibility of data and findings: "trust the culture and check out your hunches" (p. 49). We debriefed continually, and attempted member checking on the interviews. One researcher's Montessori background, knowledge, and experience proved helpful in adapting the protocol from use in a traditional educational setting to a Montessori one. Limitations occurred with participants' self-reporting as well as our interpretations as we present the data (Glesne, 2011). The study included a small sample and limited generalizability. Other limitations include differences among public, charter, and private schools; school size; supervisory qualifications and training; Montessori teacher training; and existing systems that support leaders' professional growth and capacity. Variance in roles of the school leaders, their authority, expertise, and experience, as well as the experience of the participating teachers, should also be considered. Additionally, the coaching protocol was not originally developed and piloted in Montessori schools. Further, we were participatory researchers, with one of us a Montessori educational leader for over 30 years, which can present additional bias. We kept these limitations in mind as we shared our findings with each other.

\section{Findings and Discussion}

Writing the analysis, we chose Golden-Biddle and Locke's (2006) approach, in which respondents' quotations and comments are integrated with connections to the literature and researchers' interpretations. The next sections provide narrative on and elaboration of the three identified themes, with illustrative quotes from the school-leader participants. Pseudonyms were used to ensure anonymity of the participants. Not all participants are represented in the quotes because of space limitations, but the majority of voices are expressed. Analysis of multiple cases suggests the Montessori school leaders found the coaching protocol a useful tool for facilitating their own professional reflection, improving their supervisory practice, and positively influencing teacher reflection. The participants articulated that the process created a new space for converting postobservation teacher feedback from one-way discussion into a more reflective, informative, and inquiry-based dialogue with their teachers (York-Barr et al., 2016). Just as Houchens et al. (2017) used theories of practice to describe how principals could improve their instructional leadership and practice through double-looping, these participants also began to reflect on and question their own assumptions, beliefs, and previous behaviors, and to articulate potential changes in their actions with their teachers.

\section{Leader Self-Reflection}

Research Question 1: How can a Montessori school leader's self-reflection be facilitated through the use of a prescribed coaching protocol?

Throughout their interviews, the school leaders described changes in their beliefs, assumptions, and practices regarding supervisory approaches. Several participants reported increased confidence in creating an environment where all could be successful. School leaders tend to their own learning and effectiveness through reflection, study, and improvement (NPBEA, 2015). In keeping with Bouchamma and Basque (2012), leaders' experiential learning allows them to hone and refine supervisory skills, and it becomes part of their self-development. "Wilma" commented on her leadership growth:

I've been growing in my own leadership. It's easy for me to ask questions, but my question is a little bit more closed and doesn't invite [conversation with the teacher]. ... It was a bit of a learning curve. So, I've been trying to learn how I approach different questions. 
"Diane" explored her self-development as an instructional coach using the protocol: "I do find that I do too much talking. And I do too much external problem solving. And so, what I'm learning is that not everyone is looking for my answer."

At times, the school leaders viewed self-reflection competencies from a traditional lens. Other times, they appeared to analyze the process in light of their Montessori teacher training and experience. "Sam" described the transition from a Montessori classroom teacher working with students to a leader of adults with the Montessori lens of observing, guiding, and coaching, not managing:

My focus going forward [is] trying to make sure I'm doing more... mentoring versus managing. I'm trying to shift that mindset a little bit more because that's what we do with the students. We try and give them this opportunity to grow, but normally with adults you tend to go into management mode, which I'm trying to make sure I keep in check.

Some participants were questioning their formal roles of management and teacher evaluator, trying to shift to a mindset for a different role-instructional supervisor, helping teachers to trust them, and encouraging them to engage in reflective conversation. Several concluded that it is difficult to serve in the same role as evaluator and supervisor, to establish a trusting relationship with teachers. Formal teacher-performance evaluation differs from supervision, with the latter focusing on the development of the individual, not management of personnel (Nolan \& Hoover, 2008). Dr. Montessori (1984) advocated for the development of the human being, which aligns with Nolan and Hoover's (2008) supervisory perspectives focused on the individual's professional growth. Our participants were doublelooping, reflecting, and presenting a new paradigm that may shift their approach to coaching teachers (Houchens et al., 2017). Diane echoed the value of lifelong learning for a school leader: "It does really open up [my thinking] for conversation. And it does maintain the idea that, not only are we striving to create lifelong learners, but that we are lifelong learners." Dr. Montessori described the transformation of the Montessori teacher through a lifetime of deep reflection and commitment (Bhata, 2019). Diane's thoughts about lifelong learning for the leader may have been influenced by her Montessori teacher training and her experience as a Montessori teacher.

\section{Leading Reflective Practice}

Research Question 2: How does the use of a prescribed coaching protocol impact the Montessori school leader's ability to lead teachers in reflective practices?

This study examined a school leader's reflection as the leader empowers and motivates teachers and staff to the highest levels of professional practice and to continuous learning and improvement through meaningful post-observation discussions (NPBEA, 2015, p. 20). Similarly, AMS School Accreditation Standard 2.7 requires that the administrative leader promote a culture of participation, responsibility, and ownership (AMS, 2018 , p. 3). Analysis of the participants' transcripts provided insights into how the protocol's questions facilitated leading teachers in reflective practice and thinking about improvement of their classrooms. The school leaders' responses illustrated connections to the literature, specifically with practices of adult learning, highlighting the significance of establishment of trust, collegiality, dialogue, and partnerships to guide teacher reflection (Drago-Severson et al., 2013; TschannenMoran \& Gaereis, 2015). "Louise" described her experience in leading the Montessori teachers to use the protocol for self-reflection.

What it is I'm looking for [is the] opportunity to have a conversation with them afterwards that lends itself to a collegial conversation [regarding their teaching] And to set them at ease [and provide an] opportunity to observe and to give feedback in a really positive way and to help them to become more self-aware of their practice.

Kelley also commented on her experience.

The success was them thinking about it. And having that reflective piece, I think — again with a veteran Montessori teacher - [provided a new lens]. They have a set way of doing things, but I think adding the layer of them questioning why they are doing what they are doing [fostered new ways of thinking].

The school leaders appeared to value and connect to the principles of adult learning and Montessori concepts as they used the protocol. Several participants 
acknowledged the benefit of this constructivist approach in a Montessori community, comparing it to Dr. Montessori's leadership in a classroom environment. Possibly the school leaders' own Montessori teaching experience generalized to an understanding of how to lead adults (Bhata, 2019). The school leader, trained as a Montessorian and trying to successfully transition to leading adults, used the protocol to prepare an environment to study and discuss the teacher's work in the classroom. The leader uses observation and listening to nurture and guide the adult, much like the Montessori teacher guides the child (Bhata, 2019). Building upon relationships and mutual trust, leaders can facilitate professional growth and improvement, helping the teachers question their practices and beliefs (York-Barr et al., 2016). School leader Louise talked about building relationships and getting teachers to open up with the coaching protocol's inquiry-based questions: "It's all about relationships, and if that's not there, then forget it .... It enabled [the teachers] to open up and to be able to explain and articulate [their practice]." "Queenie" described what she perceived as a teacher's delight at the inquiry-based questions, as well as the conversation and trust the protocol yielded:

I was able to say, you know, so, what did you think? You know, how did it go? What did you think was going to happen ... and what did happen and so, the teacher who was starting [Montessori] training this week was blown away by [this protocol]. She said it was eye-opening, it was awesome, I loved it. So it was fun for me because I'm excited for her journey....

Epstein (2011) described the power of becoming a "joyous observer" in a Montessori environment (p. 2). The observational experience should connect with our behaviors and the "observer and observed participate together" (p. 2). The personal power of the leader is constructed as one method of developing relationships, thus influencing others with trust and empowerment. Queenie and other school-leader participants echoed the value of their own self-reflection and that of their teachers. They unpacked reflective practice through new lenses and reframed previously learned principles representing double-looping as posited by Houchens et al. (2017).

\section{Connections to Adult Learning}

Lillard (2017) stated that people do better when they have choice in their decisions and environments, not when others attempt to control them. Montessori teacher preparation emphasizes the concepts of transformation, humility, respect, individual autonomy, self-awareness, adaptation, and encouragement of inquiry (Bennetts \& Bone, 2020; Montessori, 1984; Steiner, 2016). Principles of adult learning parallel this thinking, allowing the leader to begin a dialogue with the teacher, to listen, and to facilitate reflective thinking. School-leader participants talked about building relationships with teachers and using the coaching-protocol questions as a framework that encouraged teachers to open up and explore their practice. Caffarella and Daffron (2013) connected adult learning and reflective practices, concluding that recognition and respect for adults is essential in planning professional development.

Concepts of teacher autonomy, relationship building, experiential learning, and opportunities for reflective practice are revealed in responses to the question "Do you think [the protocol] improves your capability to provide observations with feedback sessions?" "Kenneth" said,

\section{I definitely think so.... The strengths are that I think it can be relationship building.... The person I worked with shared that she feels very comfortable with me and is happy to talk to me anytime.}

As with the child, the leader will have the opportunity, after trust is established, to guide the teacher (Lillard, 2017). "Georgina" talked about the protocol's support in creating space for conversation and the school leader listening to the teacher.

This is the strongest [protocol] that's the most effective because it lets the conversations happen in a way that both people are prepared [for], and [they are] open to the observations and change. There's no bracing oneself, there's no defiance, and it really lets the coach listen.

With a degree of alignment to their previous Montessori teacher training, the leaders may have readily acclimated to principles of adult learning, such as respect for the autonomy of the individual. The participants reinforced that the leader must attempt to model productive and effective actions and be willing 
to hear each other's voices and interpretations, without judgment, and with respect. Principles of adult learning, embedded in leading teacher reflection, must be considered for desired change to occur (York-Barr et al., 2016).

\section{Reflective Practice for School Improvement}

Interviews yielded insightful connections linking reflective practice to school improvement. Several of the represented schools are accredited by national Montessori membership organizations and adhere to professional standards for school improvement (AMS, 2018). As in the PSEL standards (NPBEA, 2015), school improvement is defined as improvement in teaching and learning as measured by outcomes. These school-leader participants generally defined school improvement as a change in their thinking and actions, perceived change in teacher practice, or potential for improvement in evaluation strategies school-wide. "Bella" talked about potential for school improvement: "It's going to be a benefit to [teachers] and to me, to build a better school. I'm really very delighted when I walk into the classroom that I see better [Montessori] instruction." Louise reflected on the coaching protocol's influence for school improvement: "And if I hadn't invested in this [research project], I wouldn't know that it's going to be a benefit to them and to me to build a better Montessori school."

Participants reflected on potential school-wide improvements with the coaching tool, with a few articulating limitations of leadership and time availability. Time and space must be created for professional conversations to improve teacher practice and thus student learning (Rieckhoff \& Damore, 2017). "Denise" explained, "It did help us to synthesize something new. It's not necessarily something we can completely adopt school-wide, but it did cause us to reevaluate our process of when the assistant heads of schools go in and do formal evaluations." Wilma expressed hope for integrating into a practice throughout the school: "I'm wanting to use it throughout the remainder of this school year and see how we can shift how we're currently doing things schoolwide." When the question was posed about comparison to the use of other tools, several school leaders expressed dissatisfaction with their schools' current supervisory approaches, citing uncomfortable, one-way feedback approaches and the use of rubrics without a script for conversation with the teacher. Kenneth said, "I think [the protocol] helps the teacher be the reflective one, instead of the person who's doing the critique that has to be reflective on how they scored [a rubric]." Sam talked about the protocol compared to other approaches:

I didn't know that [I was using my previous lens of observing to find areas for growth]. I went in with a mindset of "What do I see going well?" Because you are always thinking, okay, what are some things that need to be worked on? I need to find those. That's the feedback I need to give somebody. And it is easy to get lost in that. With the coaching protocol, it's just that you are coaching and you are supporting the person, regardless of whether the approaches or behaviors you saw in the classroom were positive or negative.

Through the use of reflective practices, schools can critically assess current practices that move into action steps for change. Queenie talked about adopting concepts of reflective practices into the teacher evaluation process: "We implemented [the coaching protocol] into our annual review form. It made us think bigger as far as having it be more interactive and get [ting] more information [from teachers]." Georgina described the potential for longer term use of the protocol, emphasizing the conversations created, perceptions of minimized threat (Drago-Severson et al., 2013) and possibilities for change:

I think it's [the coaching protocol] going to be, long-term, the most effective [for our school]. There was no dreading it going into the conversation on either side... All of the emotional energy was put into the discussion of joyful practices..., commiserating over the challenges ... with colleagues.

Reflection represents a key component in models of school improvement. Leadership in school improvement is expected of all school administrators, including those who lead Montessori schools (AMS, 2018; NPBEA, 2015).

\section{Conclusions and Implications}

This study's results support the theory that reflective practices lead to improvement of practice with this group of Montessori school leaders and their respective teachers. The use of the coaching protocol yielded positive perceptions, and participants reported improved 
individual reflection and teacher reflection. We assert that this coaching protocol is universal and affords improvement in instructional leadership through selfreflection, and leading teachers in self-reflection and improvement of practice. In her writings, Dr. Montessori did not commonly use the specific term "reflection." Yet Dr. Montessori was a model leader in her own right, a student of observation and human behavior. Thus, as researchers we equated these characteristics to leadership and reflective practices. The coaching protocol may be particularly relevant for Montessori school leadership, given the strong psychological orientation of Montessori pedagogy and its emphasis on guiding auto-education, respecting the autonomy of the individual, which parallels best practices in adult learning. The theories of practice (Houchens et al., 2017) also align with Montessori principles in its approach to supervision of teachers: study, learn, and consider other perspectives. The schoolleader participants continued to study and reflect on their experiences as reported in their interviews with us.

Because of limited resources and decentralized organizational structures, our Montessori school leaders assume numerous, conflicting administrative and supervisory roles. The tensions of simultaneously serving as a teacher evaluator and an instructional coach may not be advantageous to building trust with teachers for reflective practices (Nolan \& Hoover, 2008). This study focused on reflective practices, not teacher evaluation, although participants identified potential opportunities to incorporate reflective-practice strategies into their teacher-performance evaluation systems. Implications for future research suggest continued study of the coaching protocol, such as comparisons between traditional and Montessori school leaders and the use of existing surveys of reflective practice (Saylor et al., 2018). Although the protocol included questions about the diverse learners in teachers' classrooms, future studies may want to more directly address issues of diversity, racial equity, and inclusivity. Implications for practitioners should focus on content for Montessori professional development and schools' administration training programs, supporting that observation, reflection, and decision-making are central for school leadership, teacher efficacy, and schoolimprovement efforts.

The Montessori school leader may use observation, study, and listening to nurture and guide the adult, much like the Montessori teacher does (Bhata, 2019).
Montessori pedagogy shifts the role of the school leader in the ways of guiding children to guiding adults, using choice and auto-education, and reflective practice. Postclassroom-observation feedback cannot be one-way and prescriptive but must be meaningful, mutual, and participatory and must afford opportunities for teachers to articulate, own, and improve teaching and learning.

\section{Author Information}

\section{+ Corresponding Author}

Sharon Damoret is a Montessori leadership consultant and adjunct faculty in the College of Education, DePaul University, Chicago, Illinois. She can be reached at sjdamore@aol.com.

Barbara Rieckhoff is an associate dean in the College of Education, DePaul University, Chicago, Illinois. She can be reached at brieckhoff@depaul.edu.

\section{References}

Aguilar, E. (2013). The art of coaching. Jossey-Bass. American Montessori Society. (2018). American Montessori Society school accreditation standards and criteria. https://amshq.org/Educators/MontessoriSchools/AMS-Accreditation/Accreditation$\underline{\text { Standards }}$

American Montessori Society. (2019). American Montessori Society. https://amshq.org/AboutMontessori/History-of-Montessori/Who-WasMaria-Montessori/Maria-Montessori-Quotes

American Montessori Society. (2021). Pathway of continuous school improvement: An invitation for member schools to engage with Montessori quality. https://amshq.org/Educators/Montessori-Schools/ Pathway-of-Continuous-School-Improvement

Argyris, C., \& Schön, D. (1974). Theory in practice: Increasing professional effectiveness. Jossey-Bass.

Bagby, J., \& Sulak, T. (2013). Connecting leadership development to Montessori practice. Montessori Life, 25(1), 6-7.

Bennetts, K., \& Bone, J. (2020). Montessori literature through the lens of leadership. Journal of Montessori Research, 6(2). https://doi.org/10.17161/jomr. $\underline{\mathrm{v} 6 \mathrm{i} 2.13537}$ 
Bhata, P. (2019). The Montessori differences: Understanding its essential elements. Tomorrow's Child. 12-14.

Bogdan, R., \& Biklin, S. (2007). Qualitative research for education: An introduction to the theories and models (5th ed.). Pearson.

Bouchamma, Y., \& Basque, M. (2012). Supervision practices of school principals: Reflection in action (ED535512). ERIC. US-China Education Review B, 7, 627-637. https://files.eric.ed.gov/fulltext/ ED535512.pdf

Brockbank, A., \& McGill, I. (2012). Facilitating reflective learning, coaching and supervision (2nd ed.). Kogan Page.

Caffarella, R. S., \& Daffron, S. R. (2013). Planning programs for adult learners: A practical guide. JosseyBass.

Clark, R. W. (1999). Effective professional development schools. Agenda for Education in Democracy Series. Volume 3. Jossey-Bass.

Creswell, J. W. (2013). Qualitative inquiry \& research design: Choosing among five approaches (3rd ed.). Sage Publications.

Damore, S., \& Rieckhoff, B. (2019). School leader perceptions: Coaching tool and process. Journal of Research in Leadership Education, 16(1), 1-24. https://doi. org $/ 10.1177 / 1942775119868258$

Dewey, J. (1933). How we think. D. C. Heath.

Drago-Severson, E., Blum-DeStefano, J., \& Asghar, A. (2013). Learning for leadership: Development strategies for building capacity for schools. Corwin Press.

Elliot, V., \& Shiff, S. (2001). A look within: Staff development using structure, inquiry, and reflection to examine feelings about equity. Journal of Staff Development, 22(2), 39-42.

Epstein, P. (2011). An observer's notebook - learning from children with observation C.O.R.E. (2nd ed.). The Montessori Foundation Press.

Glesne, C. (2011). Becoming qualitative researchers: An introduction (4th ed.). Pearson.

Golden-Biddle, K., \& Locke, K. (2006). Composing qualitative research. Sage Publications.

Hallinger, P., \& Heck, R. H. (2011). Reassessing the principal's role in school effectiveness: A review of empirical research, 1980-1995. Educational Administration Quarterly, 32(1), 5-44. https://doi. org/10.1177/0013161X96032001002
Houchens, G. W., \& Keedy, J. (2009). Theories of practice: Understanding the practice of leadership. TopSCHOLAR: The Research \& Creative Activity Database of Western Kentucky University. Journal of Thought, 44, 49-66. https:// digitalcommons.wku.edu/ed leader fac pubs/3/

Houchens, G. W., Stewart, T. A., \& Jennings, S. (2017). Enhancing instructional leadership through collaborative coaching: A multi-case study. International Journal of Mentoring \& Coaching in Education, 6(1), 34-49. https://doi.org/10.1108/ IJMCE-07-2016-0057

Kapustka, K., \& Damore, S. (2012, April 13-17). "How did your students learn? How do you know?” Helping student teachers articulate student learning [Paper presentation]. American Educational Research Association Annual Meeting, Vancouver, BC, Canada.

Knight, J. (2019). Why teacher autonomy is central to coaching success. Educational Leadership, 77(3), 1420. http://www.ascd.org/publications/educationalleadership/nov19/vol77/num03/Why-TeacherAutonomy-Is-Central-to-Coaching-Success.aspx

Lillard, A. S. (2017). Montessori: The science behind the genius (3rd ed.). Oxford University Press.

Meier, D. R., \& Henderson, B. (2007). Learning from young children in the classroom: The art and science of teacher research. Teachers College Press.

Montessori, M. (1970). How it all happened: Summary of a talk to her students on January 6, 1942, describing first the Casa dei Bambini. Communications: Journal of the Association Montessori Internationale, 2/3, 2-7. https://montessoriteacherscollective.com/words. $\underline{\mathrm{html}}$

Montessori, M. (1984). The absorbent mind. (C.A. Claremont, Trans.). Dell Publishing. (Original work published 1949)

National Policy Board for Educational Administration. (2015). Professional standards for educational leaders. Author.

Nolan, J., Jr., \& Hoover, L. A. (2008). Teacher supervision and evaluation: Theory into practice. John Wiley and Sons.

Rieckhoff, B., \& Damore, S. (2017). Beyond Charlotte: Reflection for continuous improvement. Journal of Practitioner Research, 2(1), 1-14. http://doi. org/10.5038/2379-9951.2.1.1044 
Saylor, L., McKenzie, G., \& Cebulski-Sacco, C. (2018). Teacher-centered mentorship as meaningful professional Montessori development. Journal of Montessori Research, 4(2), 10-24. https://doi. org/10.17161/jomr.v4i2.6923

Schön, D. A. (1983). The reflective practitioner: How professionals think in action. Berrett-Koehler.

Senge, P., Cambron-McCabe, N. H., Lucas, T., Smith, B., Dutton, J., \& Kleiner, A. (2012). Schools that learn: A fifth discipline field book for educators, parents, and everyone who cares about education (2nd ed.). Currency.

Steiner, M. (2016). Freeing up teachers to learn: A case study of teacher autonomy as a tool for reducing inequalities in a Montessori school. Forum, 58(3), 421427. https://doi.org/10.15730/forum.2016.58.3.421

Teitel, L. (2003). The professional development schools handbook: Starting, sustaining, and assessing partnerships that improve student learning. Corwin Press.
Tschannen-Moran, M., \& Gaereis, C. (2015). Faculty trust in the principal: An essential ingredient in high-performing schools. Journal of Educational Administration, 53(1), 66-92. https://doi.org/10.1108/ JEA-02-2014-0024

Yendol-Hoppey, D., \& Dana, N. (2007). The reflective educator's guide to mentoring: Strengthening practice through knowledge, story and metaphor. Corwin Press.

York-Barr, J., Sommers, W., Ghere, G., \& Montie, J. (2016). Reflective practice for renewing schools: An action guide for educators. Corwin Press.

Zainal, Z. (2007). Case study as a research method. Jurnal Kemanusiaan, 5(1), 1-6. https://jurnalkemanusiaan. utm.my/index.php/kemanusiaan/article/down$\underline{\text { load } / 165 / 158}$ 


\section{Appendix A}

Interview Questions for Instructional Supervisors

(Questions and topics include curriculum planning/delivery; diverse needs of students; evidence of learning; adult communication and professional growth; reflective practice/inquiry.)

1. Please share the strengths of the protocol.

2. Please share areas of improvement on the protocol.

Follow-up Questions (if answers are not shared in the above open-ended, broad questions)

1. How easy or difficult was the use of the protocol for you?

2. Did you see improvement in instructional practices among participating teachers?

3. What was the average meeting time for the post-observation conference and protocol questions and answers?

4. Did this improve your capability to provide observations with feedback sessions to teachers?

5. Did this improve your teachers' abilities to improve their own teaching practices?

6. Which questions/topics appeared to be the most valuable?

7. How does it compare to other observation tools you have used/experienced?

8. Would you continue to use the protocol? Why or why not? Other comments? 